\begin{tabular}{|l|l|l||}
\hline \multicolumn{2}{|c|}{ PublisherInfo } \\
\hline \hline PublisherName & $:$ & Palgrave Macmillan UK \\
\hline \hline PublisherLocation & $:$ & London \\
\hline \hline PublisherImprintName & $:$ & Palgrave Macmillan \\
\hline \hline
\end{tabular}

\title{
Modernising the UK's National Accounts
}

\begin{tabular}{|c|c|}
\hline \multicolumn{2}{|c|}{ ArticleInfo } \\
\hline ArticleDOI & 10.1057/palgrave.elmr.1410058 \\
\hline ArticleCategory & Feature \\
\hline ArticleFirstPage & 32 \\
\hline ArticleLastPage & 38 \\
\hline A tiololian & RegistrationDate : 2007-4-20 \\
\hline & : 2007-4-20 \\
\hline ArticleCopyright & Crown copyright 2007 \\
\hline
\end{tabular}


Jon Beadle, ${ }^{\text {Aff1 }}$

Aff1 Office for National Statistics

\section{Describes modernising the UK's National Accounts at the forefront of a major programme involving ONS's statistical systems and processes.}

The Office for National Statistics is engaged in a major programme modernising its statistical systems and processes. National Accounts modernisation is at the forefront of this programme and will bring significant improvements in the quality of National Accounts estimates. This article describes these systems and processes. In order to carry forward modernisation, ONS has had to reprioritise and reduce the scope of Blue Book 2007. Thiswill mean some additional, temporary uncertainty about the quarterly path of GDP. When completed, National Accounts modernisation will mean more coherent estimates less prone to revision, consolidating the position of the UK's National Accounts as being among the best in the world.

Misc

The Full Text of this article can be found on the National Statistics website (http://www.statistics.gov.uk/elmr/04_07/downloads/ELMR_April07_Beadle.pdf). 